\title{
Leveraging Financial Performance for Recruitment and Retention of Intellectual Capital through Financial Participation
}

\author{
SANIA USMANI \\ Assistant Professor, Management \& HR Department, Institute of Business Management. \\ Email: Sania.usmani@iobm.edu.pk \\ Tel : 0092-333-3442468
}

\begin{abstract}
In recent years, substantial attention has been given to the impact of Financial Participation on Financial Performance. However, there is a lack of research of the impact of Financial Performance on Financial Participation and the mediating role of Fnancial Participation between Financial Performance, Employee Recruitment and Employee Retention. In this paper, Financial Performance, Financial Participation, Employee Recruitment and Employee Retention is examined, including two types of financial participation; Employee Stock Options and Profit Sharing. The purpose of this research was to understand the role of financial participation in attracting individuals and retaining them. Non-probability-based convenience sampling technique was used in this study. The technique was used mainly due to ease of access of respondents, geographical proximity and cost-effectiveness (Etikan et al. 2016). Structural Equation Modelling was applied on the data analysis using Partial Least Squares method on SMART-PLS Software. Drawing on the data collected from 211 respondents from various national and multinational companies in the FMCG Sector of Karachi, Pakistan. The results indicated that Financial Participation has important interaction effects with Financial Performance, Employee Recruitment and Employee Retention. It is also found that indirect effect of Financial Participation has a strong mediating relationship with Employee Retention as compared to Employee Recruitment. The findings suggest that by incorporating financial participation by employees, HR can effectively recruit and retain better individuals. Also, ESOPs are a better form of attracting and retaining better employees.
\end{abstract}

Keywords: Employee Stock Ownership, Financial Participation, Profit Sharing, Financial Performance, Employee Recruitment, Employee Retention.

\section{Introduction}

The day to day increases in competitive pressures, rapid technological change, and environmental volatility have led organizations to apply new forms of human resource practices. These include increased employee participation in the decision making, and teamwork, which can be a result of financial participation given by the organization. Financial participation involves stock options which might induce workers to be more motivated and involve in decision making and work for the welfare of the firm. Relationship between firm performance and financial participation indicates the adoption of schemes that allow employees to participate in share ownership and profits (Han, et al, 2020).

Most studies emphasize on particular forms of the financial participation but does not compare the impact of different financial participations. Financial performance has received significant attention from different scholars. Financial performance has effects on an organization's strength and ultimately its existence (Onduso, 2013). 
Financial performance is the measure of the company's operations and policies in the monetary terms. It's a general measure which shows the financial health in a given time period, and it can be used to compare with similar companies in the same industry or other industries. There are different ways to analyze a company's financial performance. That may be Return on Assets (ROA), Return on Investment (ROI) amongst others (Mishkin, 2007).

Firm's place importance on maximization of the shareholder's wealth. Managers are concerned about maximizing shareholder's wealth. Naser, Karbhari, and Mokhtar (2004) say that better performance redirects management efficiency and effectiveness in creating usage of organizations resources. According to Lazaridis, (2006) the highest predicament in financial management is to achieve preferred trade-off between solvency, profitability, and liquidity, and seeking to maximize shareholder wealth.

Financial participation is said to have a considerable influence on the employee retention and other job attitudes (Ismail, 2011). Once the employees are owners then they can act and think like owners to become more accountable and responsible for organizational results. Research on Financial Participation, such as Employee share ownership (ESO) and Profit Sharing (PS) has been continuously growing since last two decades (Kruse. Park \& Blasi., 2010; Rosen., Case, \& Staubus., 2005).

In the Economics and Industrial relations literature, it has been argued that Employee share ownership (ESO) and Profit Sharing (PS) increases employee welfare (Pendleton., 2006). PS and ESO has positive effects in recruiting new employees but it is still not clear if it has effects on retention of employees. Employee Recruitment is described as the staffing of employees in organization. It is the technique management uses to hire employees (Khatri, 2000). While Employee Retention is described as the turnover intention amongst employees. Weltmann, Blasi, and Kruse, (2015) found that employee ownership has a positive effect on employee attitudes such as job satisfaction and turnover with complementary HR policies in large multinational companies. They provided empirical evidence that employee ownership when in interaction with HR policies has an effect on attitudes.

Blasi, Freeman, Mackin, and Kruse, (2008) measured the effect of shared capitalism on six workplace outcomes; turnover, absenteeism, employee perception of discretionary effort of coworker, employee loyalty, employee willingness to work and frequency of participation. They used the term shared capitalism alternatively to financial participation. The results highlighted that shared capitalism reduces turnover, increases loyalty and willingness to work, combined with high-performance policies, fixed pay and low levels of supervision. The most prominent results were for profit sharing and gain sharing. Employees highlighted that cash incentives, stock options, ESOP, and ESPP motivate them. Important results were found between financial participation programs or shared capitalism on workplace performance (Blasi, et al, 2008).

High performance policies were positively associated with workplace outcomes, and were driven by certain types of financial participation or shared capitalism programs. Shared capitalism increases worker monitoring. Various shared capitalism operates through corporate culture. Shared capitalism and highperformance policies when combined have greater effects as compared to when they are used separately (Blasi, et al, 2008).

Since the 1970s an increasing number of studies concentrated on the relationship between changes in attitudes and behavior of employees and financial participation as well as firm's performance. Much of that research was initiated in UK and USA, while limited number of researches originated in Europe and other parts of world. Most of the studies emphasized on one type of financial participation, such as Employee Share Ownership (ESO) or Profit Sharing (PS). Therefore, this study has focused its attention on the developing economy of Pakistan. 
The core objective of research is to understand and study impact of organization financial performance and financial participation on recruitment and retention of employees. This study is carried out in order to analyze the mediating role of financial participation between financial performance of the firm and recruitment and retention of employees.

\section{Literature Review}

Profit Sharing (PS) directly depends upon the organization's performance and revenues (Poutsma de Nijs, \& Doorewaard, 1999). Employee Share Ownership (ESO) includes the employees share ownership in the organization in which they are working (Dow \& Putterman, 2000). Both these forms of financial participation are performance based, therefore bonus has into been included in this study which is separate from performance-based rewards (Cin, Han \& Smith, 2003).

PS and ESO changes with the degree of employee performance and cost effectiveness of the company. PS programs regularly offer instant participation in financial earnings of organization than ESO (Poutsma et al., 1999). With PS, financial advantage in comparatively short term (generally on yearly basis). In the ESO, employee participation in financial earnings of company is in the shape of dividends and stock price appreciation which is in longer term (Pendleton, 1997).

Furthermore, financial participation of PS includes financial earnings only. In comparison, ESO also involves decision making power in terms of voting rights during shareholder meetings (Marchington Goodman, Wilkinson, \& Ackers, 1992). Participation in authority is added from ESO that might create uncertainties and employee shares might be held in the belief that controls on managements behalf (Blasi, Kruse, Sesil, \& Kroumova, 2003). Therefore, employees have a marginal ownership in the organization. Thus, they are not owners of the cooperatives but at least have a portion of ownership in the organization (Dow., 2003). The share capital of employee participation is generally limited to slight proportion of the company's overall equity base (Boatright., 2004). For instance, Employee Share Ownership of European Foundation had less than 6\% (Six percent) of employee rights of the entire equity capital (EFES., 2013). In this research we emphasis on Pakistan, where ESO is not used as extensive as in many other European countries such as France, UK, and Italy (, Lowitzsch., Hashi \& Woodward., 2009).

In the literature of Industrial Relations, the Financial Participation is common and ESO is a major factor for employee involvement. Another important constituent of the employee participation is the degree of passive behavior which influences involvement, such as employee suggestions on the financial results and objectives of the organization. Organizations that include their employees more actively may involve employees using their suggestions or feedback, introducing quality circles or combined management/employee consultation groups or self-driven work groups (Becker \& Huselid., 2006; Freeman, 2007).

Han, et al, (2020) examined the effects of workforce racial diversity on financial performance, voluntary turnover and individual affective commitment using broad based stock options as a moderator. They identified broad based stock options as a key internal organizational attribute that facilitate racial diversity which reduces social categorization and relational problems. Productive intergroup dynamics can be promoted in a racially diverse workforce using broad based stock options. Broad-based stock options increase the goal of achieving the financial performance of the firm and create interdependence amongst employees for attaining those goals (Han, et al, 2020). The use of broad-based stock options promotes motivation by increasing employees' sense of responsibility and psychological ownership (Cappelli et al. 2020; Sieger et al. 2013). Use of broad-based stock options was taken as an internal motivational environment to determine the effects of racial diversity and understanding its effect on individual and organizational outcomes. They used the social interdependence theory which suggests that the structure of goals and rewards determine how people interact and perform collectively and that instrumental aspects of people are more important than social or personal. They found that racial diversity increases financial 
performance and commitment, reduces voluntary turnover through the use of broad-based stock options. Also, when broad-based stock options were not used, racial diversity increased voluntary turnover rates and reduced affective commitment and financial performance gains.

John and Morris (2011) used three main indicators to analyze the financial performance of organizations; Return on Equity (ROE), Return on Sales (ROS), and Return on Assets (ROA). Each ratio is calculated by dividing overall assets, overall common equity, and overall net sales, to net income individually.

Past researches have focused on the impact of stock options granted to Executives or CEO's and less research has been conducted on influence of stock options granted to lower level executives or employees. Further, past research has limited insights on the relationship between performance and broad-based stock options, with some documenting positive effects while others not finding any relationship (Hochberg and Lindsey 2010; Ittner et al. 2003, Aboody et al. 2010).

This study offers a framework in which an organization's financial performance effects the use of a financial participation (employee stock compensation plan and profit-sharing plans) and increased recruitment and retention of employees. The findings of this study contribute to the compensation literature. The current study assessed the financial performance using return on equity, earnings per share and profitability.

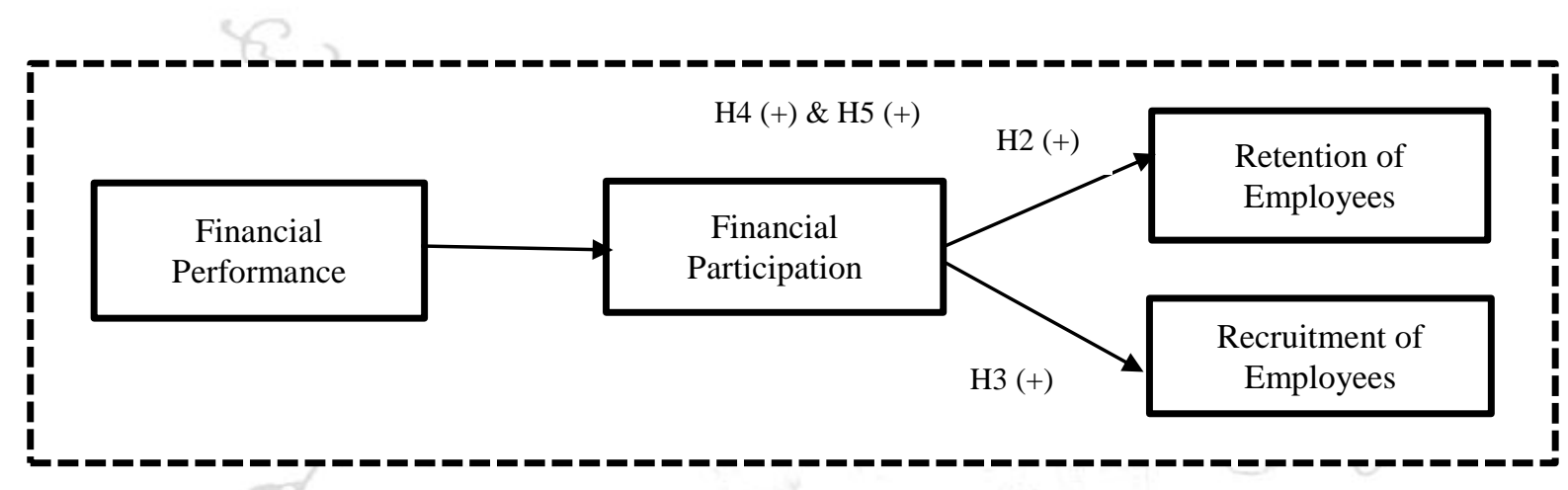

Figure 1. Conceptual Framework

\section{Hypotheses}

H1: Financial Performance positively impacts Financial Participation.

H2: Financial Participation positively impacts Employee Retention.

H3: Financial Participation positively impacts Employee Recruitment.

H4: Financial Participation mediates the relationship between Financial Performance and Employee Retention.

H5: Financial Participation mediates the relationship between Financial Performance and Employee Recruitment.

\section{Research Methods}

To test the hypotheses in this study, quantitative research methods were used. Primary data was collected from national and multi-national organizations using survey method including Engro Foods, Continental biscuits Limited, Pepsi, Muller and Philips, Coca Cola and Unilever in Karachi, Pakistan. The data was collected from Top 10 FMCG companies in Karachi Pakistan (Sales professionals Forum (2020), through personal visits as well as through email. Non-Probability based sampling technique (convenience) was used. The participants were chosen carefully based on their profile through LinkedIn and then proceeded 
from there onwards. They were directly contacted, few were contacted through personal reference also. A questionnaire was adapted and sent to 300 employees. The employees were instructed properly to fill the questionnaire. After removing unfinished survey forms a total of 211 questionnaires (70\% response rate) were retained and taken further for analysis of results. Out of 211, 97 were collected through email while 114 were collected through face to face interaction. All the responses received were fit for analysis and did not show any common method bias. SPSS and Warp PLS tool for summarizing and analyzing the data.

\section{Measures}

The questionnaire involved two Dependent Variables; Employee Recruitment and Employee Retention, one Mediator namely Financial Participation and one Independent Variable namely, Financial Performance. Employee Recruitment has three scale items which were adopted from Khatri (2000) and three scale items for Employee Retention were adopted from the Langford (2009). All scale items used five-point Likert scale with 1 = strongly disagree, $2=$ disagree, $3=$ neither disagree nor agree, $4=$ agree and $5=$ strongly agree.

Five scale items evaluated the Financial Performance were adapted from Inman et al. (2011) created by Claycomb, et al. (1999) and also validated in other research studies such as. Green and Inman (2005) and Green, et al., (2004). Financial Performance used a 7-point Likert scale secured with far worse (1), worse (2), neutral (3), better (4) and far better (5). Financial Participation scale was adopted from Kruse, Blasi, and Park, (2008). Financial Participation described if employees received profit sharing and from the company profit and that include 6 items scale and here used two-point scale that has $1=$ Yes and $2=$ No. Few demographic variables were also asked, which included, Gender, Age, Employment Status, Education and Professional Experience. The demographic characteristics of employees are summarized in the Table 1. Table 2 shows the descriptive statistics; mean, standard deviations and correlations of all the constructs. In this study, Harman's single test factor (Harman 1976; Podsakoff, 2003; Lindell and Whitney, 2001) was used to test the common method biasness and it was found that there is no method biasness in this study. There was no evidence of the method biasness.

Table 1. Demographic Characteristics

\begin{tabular}{|lll|}
\hline Variables & Frequency & Percentage \\
\hline Gender & 115 & 54.5 \\
\hline Male & 96 & 45.5 \\
\hline Female & & \\
\hline Age & 101 & 50 \\
\hline $20-29$ & 88 & 40 \\
\hline $30-39$ & 22 & 10 \\
\hline $40-49$ & & 82 \\
\hline Employment Status & 174 & 18 \\
\hline Permanent & 37 & 34 \\
\hline Part-time & & 66 \\
\hline Education & 71 & \\
\hline Bachelor & 140 & 41.5 \\
\hline Master & & 24.1 \\
\hline Professional Experience & 88 & 17.0 \\
\hline Less than or equal to 5 years & 51 & 9.0 \\
\hline Less than or equal to 10 years & 36 & 7.5 \\
\hline Less than or equal to 15 years & 19 & \\
\hline Less than or equal to 20 years & 17 & \\
\hline More than 20 years & & \\
\hline Ne211 & & \\
\hline
\end{tabular}

$\mathrm{N}=211$ 
Table 2. Descriptive Statistics and Correlations

\begin{tabular}{|lllllll|}
\hline Variables & Mean & SD & 1 & 2 & 3 & 4 \\
\hline Employee Recruitment & 11.18 & 2.684 & - & - & - & - \\
Employee Retention & 9.611 & 3.298 & $.118^{*}$ & - & - & - \\
Financial Performance & 18.53 & 3.699 & $.002^{*}$ & $.234^{* *}$ & - & - \\
Financial Participation & 9.15 & 2.050 & $.113^{*}$ & $.243^{* *}$ & $.449 * *$ & - \\
\hline
\end{tabular}

Correlation $\mathrm{p}<0.01^{* *} ; \mathrm{p}<0.05^{*}$

\section{Analysis}

In this study we used Partial least squares (PLS) method for structural equation modelling (SEM) aided by SPSS 19.0 (Armonk, NY: IBM Corp) and WarpPLS 6.0 softwares (Kock, 2019) to test the hypotheses. This method is most suitable with minimum sample size as suggested by Henseler et. al (2014). The data analysis in this study was comprised of two stages. In the first stage, the measurement model was developed in which reliability and validity of the constructs was analyzed. The second stage was the development of structural model to test the causal and mediation hypotheses.

In this study measurement model was developed in which confirmatory factor analysis was carried and all the items were loaded on priori of their constructs, (Brown \& Moore, 2012). The explanation of the measurement scales and items applied in this study are summarized in table 3. Table 3 shows all the standardized loadings of the factors, and coefficients of reliability and validity. All relevant items were loaded on their constructs excluding one item with lowest cross loading in the financial participation construct which was dropped from model; FINPA6

\section{Table 3. Measurement Model}

\begin{tabular}{|lc|}
\hline Variables & $\begin{array}{c}\text { Standardized loadings and the coefficients of } \\
\text { reliability and validity }\end{array}$ \\
\hline Employee Recruitment (VIF= 1.461) & AVE $=0.772, \alpha=0.854, \mathrm{CRC}=0.911$ \\
REC1 & $\alpha=0.808$ \\
REC2 & $\alpha=0.779$ \\
REC3 & $\alpha=0.794$ \\
Employee Retention (VIF = 1.808) & $\alpha=0.866, \mathrm{CRC}=0.918$ \\
RET1 & $\alpha=0.803$ \\
RET2 & $\alpha=0.793$ \\
RET3 & $\alpha=0.849$ \\
Financial Performance $(V I F=1.142)$ & $\alpha=0.788, \mathrm{CRC}=0.928$ \\
FINPER1 & $\alpha=0.898$ \\
FINPER2 & $\alpha=0.882$ \\
FINPER3 & $\alpha=0.884$ \\
FINPER4 & $\alpha=0.894$ \\
FINPER5 & $\alpha=0.897$ \\
Financial Participation $($ VIF $=\mathbf{1 . 2 7 5})$ & $\alpha=0.846, \mathrm{CRC}=0.891$ \\
FINPA1 & $\alpha=0.786$ \\
FINPA2 & $\alpha=0.847$ \\
FINPA3 & $\alpha=0.750$ \\
FINPA4 & $\alpha=0.756$ \\
FINPA5 & $\alpha=0.874$ \\
\hline
\end{tabular}

Note: VIF (Variance Inflation factor); AVE (Average Variance Extracted); a (Cronbach's alpha); CRC, (Composite Reliability Coefficient); PLS-SEM, bootstrapping, 500 resamples, 10 iterations.

All the items with significant factor loadings in their constructs propose convergent validity. The constructs also validate the satisfactory level of items reliability, and homogeneity by satisfactory standard values of 
composite reliability and coefficients (Kock 2019). The Cronbach Alpha has high values while Composite Reliability Coefficient (CRC) also suggests strong indicators of reliability; both having minimum acceptable standard value of the 0.70 (Chin 1998).

Table 4. Fornell-Larcker Criterion

\begin{tabular}{|c|c|c|c|c|}
\hline & $\begin{array}{c}\text { Employee } \\
\text { Recruitment }\end{array}$ & $\begin{array}{l}\text { Employee } \\
\text { Retention } \\
\end{array}$ & $\begin{array}{c}\text { Financial } \\
\text { Participation }\end{array}$ & $\begin{array}{c}\text { Financial } \\
\text { Performance }\end{array}$ \\
\hline $\begin{array}{l}\text { Employee } \\
\text { Recruitment }\end{array}$ & 0.879 & - & - & - \\
\hline $\begin{array}{l}\text { Employee } \\
\text { Retention }\end{array}$ & 0.534 & 0.888 & - & - \\
\hline $\begin{array}{l}\text { Financial } \\
\text { Participation }\end{array}$ & 0.249 & 0.443 & 0.788 & - \\
\hline $\begin{array}{l}\text { Financial } \\
\text { Performance }\end{array}$ & 0.204 & 0.351 & 0.270 & 0.848 \\
\hline
\end{tabular}

After the convergent validity, discriminant validity was assessed using the Fornell - Larcker criteria, cross loadings and HTMT criteria suggested by Henseler et al. (2015) and updated by Franke and Sarstedt (2019). All the values of Fornell - Larcker criteria, cross loadings and HTMT criteria were within the threshold and thus suggested discriminant validity (Fornell - Larcker values should be greater than other constructs; cross loadings $>0.7$, HTMT $\leq 0.85$ ) as shown in Table 4, Table 5 and Table 6 . Taken together all these reliability and validity tests have shown that the measurement items are both valid and reliable.

Table 5. Cross Loadings

\begin{tabular}{|c|c|c|c|c|}
\hline 20 & $\begin{array}{l}\text { Financial } \\
\text { Participation }\end{array}$ & $\begin{array}{l}\text { Financial } \\
\text { Performance }\end{array}$ & $\begin{array}{l}\text { Employee } \\
\text { Recruitment }\end{array}$ & $\begin{array}{l}\text { Employee } \\
\text { Retention }\end{array}$ \\
\hline FINPA1 & 0.709 & 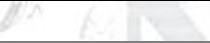 & 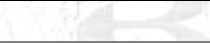 & 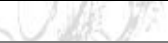 \\
\hline FINPA2 & $\begin{array}{lll}-1 \times 1 \times 1 \\
\end{array}$ & 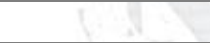 & 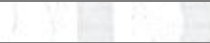 & $215 / 2$ \\
\hline FINPA3 & 18 & 2 & & 1 \\
\hline FINPA4 & 0.810 & & & Fin \\
\hline FINPA5 & 0.767 & & & $\circlearrowleft$ \\
\hline FINPER1 & & 0.789 & & \\
\hline FINPER2 & & 0.879 & & \\
\hline FINPER3 & & 0.867 & & \\
\hline FINPER4 & & 0.853 & & \\
\hline FINPER5 & & 0.851 & & \\
\hline REC1 & & & 0.859 & \\
\hline REC2 & & & 0.878 & \\
\hline REC3 & & & 0.899 & \\
\hline RET1 & & & & 0.893 \\
\hline RET2 & & & & 0.901 \\
\hline RET3 & & & & 0.869 \\
\hline
\end{tabular}

Table 6. Heterotrait-Monotrait Ratio (HTMT)

\begin{tabular}{|lcccc|}
\hline & $\begin{array}{c}\text { Employee } \\
\text { Recruitment }\end{array}$ & $\begin{array}{c}\text { Employee } \\
\text { Retention }\end{array}$ & $\begin{array}{c}\text { Financial } \\
\text { Participation }\end{array}$ & $\begin{array}{c}\text { Financial } \\
\text { Performance }\end{array}$ \\
\hline Employee Recruitment & - & - & - & - \\
\hline Employee Retention & 0.626 & - & - & - \\
\hline Financial Participation & 0.288 & 0.518 & - & - \\
\hline Financial Performance & 0.237 & 0.397 & 0.307 & - \\
\hline
\end{tabular}


Following the suggestions of Hair et. al (2019), path coefficients, standard errors, t-values and p-values for the structural model was reported using a 500-re-sample bootstrapping procedure. Table 7 and Table 8 shows the direct and indirect effects of the hypotheses developed. $\mathrm{R}^{2}$ for Financial Performance on Financial Participation was 0.074, while $\mathrm{R}^{2}$ on Employee Recruitment and Employee Retention was 0.061 and 0.2. There is positive relationship between Financial Performance and Financial Participation $(\beta=$ 0.273 , p $<0.01$ ), thus $\mathrm{H} 1$ is accepted; also, there is positive relationship between Financial Participation and Employee Retention $(\beta=0.447, \mathrm{p}<0.01)$ thus $\mathrm{H} 2$ is accepted; and there is positive relationship between Financial Participation and Employee Recruitment $(\beta=0.246, \mathrm{p}<0.01)$ thus, H3 was also supported. To test the mediation hypotheses, suggestions of Preacher and Hayes (2008) were followed by bootstrapping the indirect effect. The results for the mediation analysis show that Financial Performance has a positive effect on Employee Retention through Financial Participation $(\beta=0.122, p<0.01)$, thus H4 is accepted. Furthermore, Financial Performance has a positive effect on Employee Recruitment through Financial Participation $(\beta=0.067, \mathrm{p}<0.01)$, therefore H5 is also accepted. The confidence intervals bias corrected $95 \%$ did not show a 0 on both sides thus confirming our findings. Hence, all hypotheses are significant in this study. Figure 2 shows the structural equation modelling of the conceptual framework in this study.

Table 7. Hypothesis Testing Direct Effects

\begin{tabular}{|c|c|c|c|c|c|c|c|c|c|}
\hline & STD BETA & STD ERROR & T VALUE & P VALUES & BCIL LL & BCI UL & F2 & VIF & Hypotheses \\
\hline $\begin{array}{l}\text { Financial Performance } \\
-> \\
\text { Financial Participation }\end{array}$ & 0.273 & 0.059 & 4.647 & 0.000 & 0.176 & 0.404 & 0.079 & 1.000 & H1: Sig \\
\hline $\begin{array}{l}\text { Financial Participation } \\
\text {-> } \\
\text { Employee Retention }\end{array}$ & $\begin{array}{c}0.447 \\
5\end{array}$ & 0.055 & 8.143 & 0.000 & 0.346 & 0.570 & 0.244 & 1.000 & H2: Sig \\
\hline $\begin{array}{l}\text { Financial Participation } \\
\text {-> } \\
\text { Employee Recruitment }\end{array}$ & 0.246 & 0.061 & 4.004 & 0.000 & 0.124 & 0.362 & 0.066 & 1.000 & H3: Sig \\
\hline
\end{tabular}

$$
\mathrm{N}=211
$$

Table 8. Hypothesis Testing Indirect Effects

\begin{tabular}{|llllllll|}
\hline & STD BETA & STD ERROR & T VALUE & P VALUES & BCIL LL & BCI UL & Hypotheses \\
\hline $\begin{array}{l}\text { Financial Performance -> } \\
\text { Financial Participation } \\
\text {-> Employee Retention }\end{array}$ & 0.122 & 0.033 & 3.648 & 0.000 & 0.070 & 0.205 & H4 \\
\hline $\begin{array}{l}\text { Financial Performance -> } \\
\text { Financial Participation } \\
\text {-> Employee Recruitment }\end{array}$ & 0.067 & 0.024 & 2.806 & 0.005 & 0.029 & 0.120 & H5 \\
\hline
\end{tabular}
$\mathbf{N}=211$

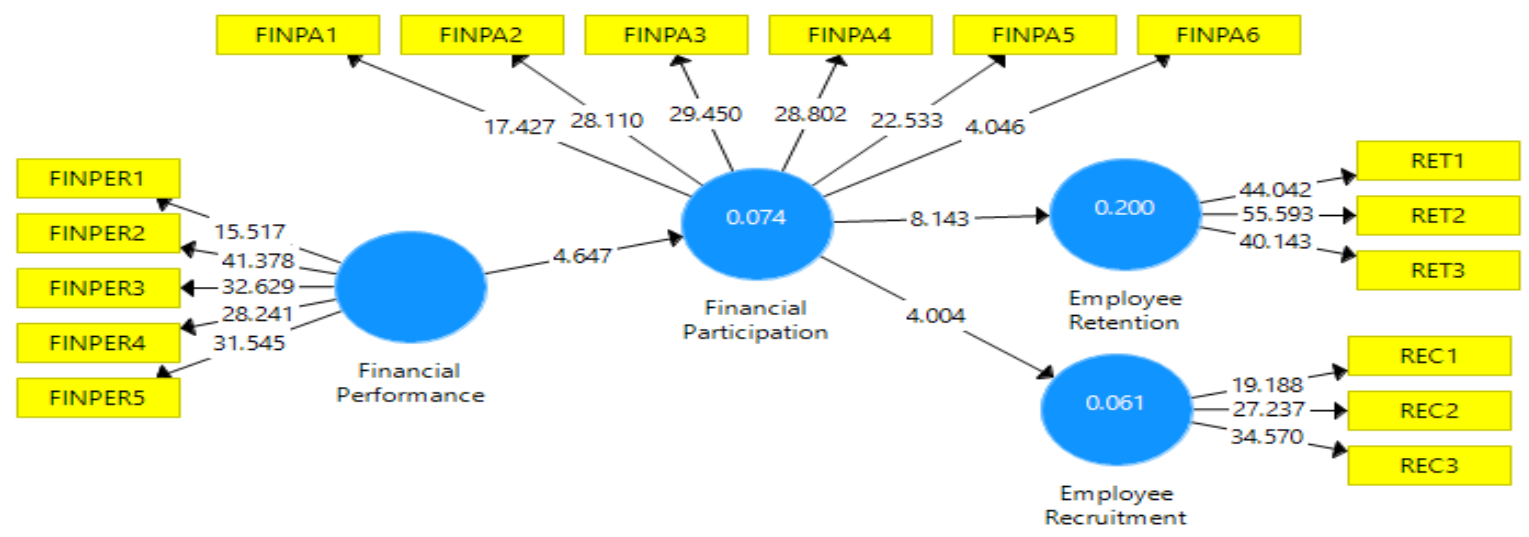

Figure 2. Structural Equation Model 


\section{Discussions}

The objective of this study was to explore the impact of financial participation as instruments to recruit and retain intellectual capital for the organization. This study supports the all the hypotheses. It was found that Financial performance leads to financial participation and financial participation increases recruitment and retention. Financial Participation leads to better Recruitment and Retention of employees as it encourages the individuals with "right characteristics" to apply for positions and therefore to develop the intellectual capital of the firm. Financial Participation enhances motivation, increases psychological ownership, increases retention and attracts better intellectual capital. These hypotheses are also supported by previous studies (Park, Kruse, \& Sesil, 2004). Financial participation creates expectations between employees and employer wehre employees are likely to contribute in managerial decision making (Pierce et al, 2001; Becker \& Huselid, 2006; Festing, Groening, Kabst, \& Weber, 1999). In order to retain employees, organizations must offer Financial Participation plans.

The results of this study have some of the important managerial implications. By providing attractive Financial Participation essentially ensures retention of employee. HR managers could implement employee stock options and profit sharing with employees to create a modest weapon in "war for talent" (Chambers, Foulon, Handfield-Jones, Hankin, \& Michaels, 1998). If the HR practices and policies are not closely linked with employees values and belief systems then it will be difficult for organizations to retain the best talent and it would result in brain drain. Recruiters and Human Resource Managers could use the contributions of this study by understanding the importance of Financial Participation and offering these schemes to applicants in effective and transparent ways which will increase the talent and retain them for longer periods of time.

\section{Limitations and Future Research}

Self-report measures might lead to common bias methods. Also, only employees were used as a sample unit for analysis. Future studies can use the data from supervisors also, as a twofold study. Focus groups and observations instead of survey method for data collection could also be used. Future studies can use diversity (Han, 2020) as a moderator in the same model and its effect on the good will of the company. Employee performance can also be taken as a mediator in the model. Lastly, other sectors can also be investigated for the generalization of this research.

\section{Conclusion}

Intellectual capital is at the heart of company performance. It is reciprocal and if a company can attract and retain good employees through financial participation then the cycle of better financial performance of company will be attained. Encouraging employees to opt for ESOP and Profit Sharing can retain them and also attract other individuals to work for the company. It is the responsibility of management to create such policies and practices in the company. Also, it is the role of the researchers to help them understand the role of ESOPs and Profit Sharing. In conclusion, it is important to adopt policies and attach those policies with the goals related to employee empowerment and involvement. This study will help managers to apply those policies.

\section{References}

Aboody, D., Johnson, N. B., \& Kasznik, R. (2010). Employee stock options and future firm performance: Evidence from option repricings. Journal of Accounting and Economics, 50(1), 74-92.

Becker, B. E., \& Huselid, M. A. (2006). Strategic human resources management: Where do we go from here? Journal of Management, 32, 898-925. 
Blasi, J. R., Kruse, D. L., Sesil, J. C., \& Kroumova, M. (2003). An assessment of employee ownership in the United States with implications for the EU. The International Journal of Human Resource Management, 14, 893-919.

Blasi, J. R., Freeman, R. B., Mackin, C., \& Kruse, D. L. (2008). Creating a bigger pie? The effects of employee ownership, profit sharing, and stock options on workplace performance (No. w14230). National Bureau of Economic Research.

Boatright, J. R. (2004). Employee governance and the ownership of the firm. Business Ethics Quarterly, $14(1), 1-21$.

Brown, T. A., \& Moore, M. T. (2012). Confirmatory factor analysis. Handbook of structural equation modeling, 361-379.

Cappelli, P., Conyon, M., \& Almeda, D. (2020). Social exchange and the effects of employee stock options. ILR Review, 73(1), 124-152.

Chambers, E. G., Foulon, M., Handfield-Jones, H., Hankin, S. M., \& Michaels III, E. G. (1998). The war for talent. The McKinsey Quarterly, (3), 44.

Chin, W. W. (1998). The partial least squares approach to structural equation modeling. Modern methods for business research, 295(2), 295-336.

Cin, B. C., Han, T. S., \& Smith, S. C. (2003). A tale of two tigers: Employee financial participation in Korea and Taiwan. The International Journal of Human Resource Management, 14(6), 920-941.

Dow, G. K. (2003). Governing the Firm. Cambridge, MA: Cambridge University Press.

Dow, G. K., \& Putterman, L. (2000). Why capital suppliers (usually) hire workers: What we know and what we need to know. Journal of Economic Behavior \& Organization, 43, 319-336.

Etikan, I., Musa, S. A., \& Alkassim, R. S. (2016). Comparison of convenience sampling and purposive sampling. American Journal of Theoretical and Applied Statistics, 5(1), 1-4.

European Foundation of Employee Share Ownership (EFES). (2013). Typology of employee ownership. Retrieved from http://www.efesonline.org/fasuk301.htm

Festing, M., Groening, Y., Kabst, R., \& Weber, W. (1999). Financial participation in Europe determinants and outcomes. Economic and Industrial Democracy, 20, 295-329.

Freeman, S. F. (2007). Effects of ESOP adoption and employee ownership: Thirty years of research and experience. (Working Paper No. 07-01). Philadelphia, PA: Organizational Dynamics Programs, University of Pennsylvania.

Franke, G., \& Sarstedt, M. (2019). Heuristics versus statistics in discriminant validity testing: a comparison of four procedures. Internet Research, 29(3), 430-447.

Hair, J., Risher, J., Sarstedt, M.,\& Ringle, C. (2019), When to use and how to report the results of PLSSEM. European Business Review, 31(1), 2-24.

Han, J. H., Shin, D., Castellano, W. G., Konrad, A. M., Kruse, D. L., \& Blasi, J. R. (2020). Creating Mutual Gains to Leverage a Racially Diverse Workforce: The Effects of Firm-Level Racial Diversity on Financial and Workforce Outcomes Under the Use of Broad-Based Stock Options. Organization Science.

Harman, H. H. (1976). Modern factor analysis. University of Chicago press.

Henseler, J., Ringle, C., \& Sarstedt, M. (2015). A New Criterion for Assessing Discriminant Validity in Variance-based Structural Equation Modeling. Journal of the Academy of Marketing Science, 43(1), 115-135.

Henseler, J., Dijkstra, T. K., Sarstedt, M., Ringle, C. M., Diamantopoulos, A., Straub, D. W., \& Calantone, R. J. (2014). Common beliefs and reality about PLS: Comments on Rönkkö and Evermann (2013). Organizational research methods, 17(2), 182-209.

Hochberg, Y. V., \& Lindsey, L. (2010). Incentives, targeting, and firm performance: An analysis of nonexecutive stock options. The Review of Financial Studies, 23(11), 4148-4186.

Ittner, C. D., Lambert, R. A., \& Larcker, D. F. (2003). The structure and performance consequences of equity grants to employees of new economy firms. Journal of Accounting and Economics, 34(1-3), 89127.

Kock, N. (2019). Factor-based structural equation modeling with WarpPLS. Australasian Marketing Journal (AMJ), 27(1), 57-63. 
Kruse, D. L., Blasi, J. R., \& Park, R. (2010). Shared capitalism in the U.S. economy: Prevalence, characteristics, and employee views of financial participation in enterprises. In D. L. Kruse,

R. B. Freeman, \& J. R. Blasi (Eds.), Shared capitalism at work: Employee ownership, profit and gain sharing, and broad-based stock options (pp. 41-75). Chicago, IL: The University of Chicago Press.

Kruse, D. L., Blasi, J. R., \& Park, R. (2008). Shared capitalism in the US economy? Prevalence, characteristics, and employee views of financial participation in enterprises (No. w14225). National Bureau of Economic Research.

Lazaridis, L. (2006). relationship between working capital management and profitability of listed companies in Athens stock exchange. Journal of financial management and analysis, 19, 5-7.

Lindell, M. K., \& Whitney, D. J. (2001). Accounting for common method variance in cross-sectional research designs. Journal of applied psychology, 86(1), 114.

Lowitzsch, J., Hashi, I., \& Woodward, R. (Eds.). (2009). The PEPPER IV Report: Benchmarking of employee participation in profits and enterprise results in the member and candidate countries of the European Union. Berlin.

Marchington, M., Goodman, J., Wilkinson, A., \& Ackers, P. (1992). New developments in employee involvement. London: Employment Department.

McNabb, R., \& Whitfield, K. (1998). The Impact of financial participation and employee involvement on financial performance. Scottish Journal of Political Economy, 45, 171-187.

Mcnabb, R., \& Whitfield, K. (1999). The distribution of employee participation schemes at the workplace. The International Journal of Human Resource Management, 10, 122-136.

Mishkin, F. (2007). Housing and transmission mechanism. Federal Reserve Bank of Kansas City, 359-413.

Naser, K., Karbhari, Y., \& Mokhtar, M. Z. (2004). Impact of ISO 9000 registration on company performance. Managerial Auditing Journal.

Onduso, E. O. (2013). The Effect Of Budgets On Financial Performance Of Manufacturing Companies In Nairobi County. New Business Journal, 7,46,74.

Park, R., Kruse, D., \& Sesil, J. (2004). Does employee ownership enhance firm survival? Advances in the Economic Analysis of Participatory and Labor-Managed Firms, 8(1), 3-33.

Pendleton, A. (1997). Characteristics of workplaces with financial participation: Evidence from the workplace industrial relations survey. Industrial Relations Journal, 28, 103-119.

Pendleton, A. (2006). Incentives, monitoring, and employee stock ownership plans: New evidence and interpretations. Industrial Relations, 45, 753-775.

Podsakoff, N. P. (2003). Common method biases in behavioral research: a critical review of the literature and recommended remedies. Journal of applied psychology, 885(879), 10-1037.

Poutsma, E., de Nijs, W., \& Doorewaard, H. (1999). Promotion of employee ownership and profit sharing in Europe. Economic and Industrial Democracy, 20, 171-196.

Preacher, K. J., \& Hayes, A. F. (2008). Assessing mediation in communication research (pp. 13-54). London: The

Sage sourcebook of advanced data analysis methods for communication research.

Rosen, C., Case, J., \& Staubus, M. (2005). Equity: Why employee ownership is good for business, Boston, MA: Harvard Business School Press.

Rousseau, D. M. (2012). Envisioning evidence-based management. In Rousseau (Ed.), The oxford handbook of evidence-based management (pp. 3-24). Oxford: Oxford University Press.Sales Professionals Forum (2020), Retrieved from, https://www.salesprofessionalsforum.com/top-ten-fmcgcompanies-pakistan/

Sieger, P., Zellweger, T., \& Aquino, K. (2013). Turning agents into psychological principals: aligning interests of non-owners through psychological ownership. Journal of Management Studies, 50(3), 361388.

Weltmann, D., Blasi, J. R., \& Kruse, D. L. (2015). Does employee ownership affect attitudes and behaviors? The role of selection, status, and size of stake. Advances in the economic analysis of participatory \& labor-managed firms, 16, 249-275. 